\title{
REGULARARTICLE \\ ON-FARM DIVERSITY ASSESSMENT AND EVALUATION OF FINGER MILLET GENOTYPES IN THE MID HILLS OF NEPAL
}

\section{RITESH KUMAR YADAV ${ }^{1^{*}}$, RITA GURUNG ${ }^{1}$, RAJEEV DHAKAL ${ }^{1}$, SUBASH GAUTAM $^{1}$, ACHYUT $^{\prime}$ RAJ ADHIKARI ${ }^{1}$, KRISHNA HARI GHIMIRE² AND BHUWON RATNA STHAPIT3}

\author{
${ }^{1}$ Local Initiatives for Biodiversity, Research and Development, Pokhara, Nepal \\ ${ }^{2}$ National Agriculture Genetic Resources Centre, NARC, Khumaltar, Nepal \\ 3Bioversity International, Pokhara, Nepal
}

\begin{abstract}
The objective of the study is to assess the phenotypic diversity among the finger millet genotypes and evaluate overall performance for the recommendation of genotypes to the farming community of mid hills of Nepal. The overall performance of 8 candidate genotypes selected from diversity block of 46 varieties in 2015, were assessed in randomized complete block design (RCBD) with three replicates under on-farm conditions in Lamjung district during 2016. Highly significant $(p \leq 0.01)$ variability among the selected 8 genotypes for agro-morphological traits viz., plant height, number of fingers per head, grain yield, 1000 grain weight, straw yield, days to heading and maturity was revealed. Strong inter-correlation among grain yield, plant height, time to flowering and straw yield was detected. The traits viz., plant height, grain yield, straw yield, days to heading and days to maturity were the most important traits contributing to the overall variability and thus, provide options for selection.
\end{abstract}

Keywords: Finger millet, On-farm, Agro-morphological traits, Diversity, Nepal

\section{INTRODUCTION}

Finger millet (Eleusine coracana Gaertn.), is an important food crop in the hills of Nepal. It can tolerate many of the abiotic stress conditions and provides nutritious staple food to millions of small holder farmers of the world $[1,2]$. Finger millet belongs to the $\mathrm{C} 4$ photosynthetic category of plants [3]. In Nepal, major area of production of finger millet was reported to lie in the mid hills between 600 to $2000 \mathrm{~m}$ above from the sea level (masl) representing more than $50 \%$ the population of Nepal but the crop is grown in diverse agroecological conditions from Terai and Inner Terai (100 masl) to valley, hills and mountain areas up to the elevation of 2500 masl [1]. Finger millet is highly valued due to its nutritional content, being especially rich in calcium, iron, manganese and methionine and tryptophan amino acids [4, 5]. Its slow digestion indicates low blood sugar levels after intake, thereby, it is a safer food for diabetics [6]. Being rich in many nutrients, this millet is highly useful to hardworking farmers metabolically disordered people.

The plant parts have been used in alternative medicine and recent reports validated that [7]. Devi et al. [8] reported health benefits of the crop both nutritive and medicinal properties. Finger millet is used in preparation of traditional food products of Nepal. Similarly, finger millet is strongly linked to the cultural value of ethnic communities such as
Gurung, Magar and Tamang and is an important crop in Lamjung where Gurung community predominates.

Finger millet can be used for extended storage as it is less susceptible to pests $[9,10]$. It can be utilized for animal feed as well. The green straw contains digestible nutrients is worthy for animal consumption [11]. In the wake of climate change, malnutrition and public health challenges, finger millet has tremendous potential to meet these challenges, provided its drought tolerance and ability to grow as monocrop, relay crop and inter-crop under low inputs conditions in diverse agro-ecology, along with other healthpromoting traits valued by humans. In this context, characterization and evaluation of landraces from ex-situ collection and on-farm, need attention as these valuable genetic resources have been poorly used [12].

The present study was undertaken with the objective of assessing the phenotypic diversity among the available germplasm and evaluating promising genotypes for their agronomic performance under on-farm conditions. The information thus generated would be of tremendous value for recommending the superior genotypes to the farming community and facilitating the choice of genitors for effective finger millet breeding programme.

Received 24 December 2017; Accepted 11 January 2018

*Corresponding Author

Ritesh Kumar Yadav

Local Initiatives for Biodiversity, Research and Development, Pokhara, Nepal

Email: ritesh.yadav@libird.org

(C) This article is open access and licensed under the terms of the Creative Commons Attribution License (http://creativecommons.org/licenses/by/4.o/) which permits unrestricted, use, distribution and reproduction in any medium, or format for any purpose, even commercially provided the work is properly cited. Attribution - You must give appropriate credit, provide a link to the license, and indicate if changes were made. 


\section{MATERIALS AND METHODS}

\section{Diversity block}

In order to assess and evaluate the phenotypic diversity among the 46 landraces, an un-replicated diversity block trial using rod row design was set up in Ghanpokhara VDC (Village Development Committee)-1 of Lamjung district in 2015 under on-farm conditions at elevation of 1515 masl. Diversity block is an experimental block of farmers' varieties managed by local institution for research and development purposes [13]. The genotypes included in the study were collected from ex-situ genebank and their sources of collection are depicted in table 1. The findings generated from the study were deployed to enable the selection of the candidate genotypes exhibiting superior agronomic performance for further evaluation in on-farm yield trial. Each landrace was planted in two rows of $3 \mathrm{~m}$ length with the plot size of $1.2 \mathrm{~m}^{2}$ with distance of $20 \mathrm{~cm}$ between row to row and $10 \mathrm{~cm}$ between plant to plant. The experiment plots were managed as per farmers' practice. The UPGMA cluster analysis based on Euclidean distance using JMP 13 was performed to group the landraces into distinct clusters. The observations on seven traits viz., time to heading and maturity, plant height, ear exertion $(\mathrm{cm})$, flag leaf length $(\mathrm{cm})$, finger width $(\mathrm{mm})$ and grain yield $(\mathrm{g}$ plot $^{-1}$ ) were recorded as per the descriptors of finger millet [14]. The data on grain yield was extrapolated in $t \mathrm{ha}^{-1}$. These traits were considered in UPGMA clustering and the genotypes to be included in the yield trial were identified from the clusters showing high trait values.

\section{Yield trial}

The yield trial was conducted during 2016 under on-farm conditions in Ghanpokhara VDC-1 of Lamjung district located at $28^{\circ} 17.397^{\prime}$ latitude North and $084^{\circ} 19.344^{\prime}$ longitude and altitude of 1525 masl. Total of eight genotypes (six selected from diversity block and two recently released varieties viz., Kabre-2 and Sailung-1) were included in the study for evaluating the agronomic performance. The genotypes included in the study along with their respective distinguishing traits and sources are presented in table 2. The field experiment was laid out in RCBD with three replications. In each replication, each cultivar was grown in a plot of 10 rows with a distance of $20 \mathrm{~cm}$ between row to row and $10 \mathrm{~cm}$ between plant to plant and the area of each experimental unit was $6 \mathrm{~m}^{2}(2 \mathrm{~m} \mathrm{x}$ $3 \mathrm{~m})$. The sowing of each genotype was done in first week of May, 2016. The local farmer's practices were followed to raise the crop. Well decomposed FYM @ 5-6 t/ha was applied in the field during land preparation. No chemical fertilizers and pesticides were used. Two hand weeding cum hoeing were performed 30 and $60 \mathrm{~d}$ after sowing (DAS), respectively. The data were recorded for seven agromorphological traits such as plant height $(\mathrm{cm})$, number of fingers/head, grain yield ( $\left.\mathrm{g} \mathrm{plot}^{-1}\right), 1000$ grain weight $(\mathrm{g})$, straw yield ( $\left.\mathrm{kg} \mathrm{plot}^{-1}\right)$, days to $50 \%$ heading and $80 \%$ maturity as per the descriptors. The data on grain and straw yield were later extrapolated to $\mathrm{tha}^{-1}$ for data analysis.

The data collected for evaluation of agronomic traits of the genotypes were subjected to analysis of variance under RCBD using statistical software R and the significance of differences between the means were compared using Least Significant Difference (LSD) at 5 percent level of significance. The Pearson's correlation coefficients between each pairs of traits and principal component analysis (PCA) was conducted using statistical software R and Minitab 15.0 in order to study the extent of association among the traits and to identify the patterns of agromorphological variation, respectively.

\section{RESULTS AND DISCUSSION}

\section{Diversity block}

The UPGMA cluster analysis based on Euclidean distance of 46 genotypes revealed five different clusters (fig. 1 and table 3). Cluster II was found to be the largest cluster containing 30 landraces with higher mean values of yield, finger width, flag leaf length and ear exertion while lower mean values for phenological traits. The cluster $\mathrm{V}$ which contained only landrace genotype viz., Lamsare Kodo also showed higher values for the desirable agronomic traits. Despite being desirable for most of the traits, cluster I, III and IV were found to be unworthy in terms of yield and phenological traits. The six landraces viz., Chhatre, Chhangre Kodo, Nangre Kodo (Lamjung), Dalle Kodo, Lamsare Kodo and Syakhkhad Kodo for displaying superior performance in terms of agronomic and phenological traits were selected for further evaluation and validation.

\section{Yield trial}

Highly significant variation was noted among the selected genotypes for all the agronomical traits viz., days to heading and maturity, plant height, number of fingers, grain yield, 1000 grain weight and straw yield. Substantial variations in finger millet have also been reported in previous studies by [15-18]. The mean performance of the genotypes for these traits are shown in table 4. NGRC01431 (Chhatre) recorded the highest plant height $(109.33 \pm 1.45 \mathrm{~cm})$ which was at par with Chhangre kodo and Lamsare kodo. Similarly, NGRCo1431 (Chhatre) recorded the highest grain yield $\left(1.80 \pm 0.06 \mathrm{t} \mathrm{ha}^{-1}\right)$ and highest number of finger (10.67 \pm 0.33$)$. NGRC05049 (Sailung-1) recorded the highest 1000 grain weight $(3.33 \pm 0.07 \mathrm{~g})$ being statistically at par with Dalle kodo and Lamsare kodo. Syakhkhad kodo recorded the highest straw yield $\left(7.61 \pm 1.03 \mathrm{t} \mathrm{ha}^{-1}\right)$ and highest number of days to $50 \%$ heading (145 \pm 1.00$)$. Similarly, Lamsare kodo was found to be the earliest to $50 \%$ heading $(136.67 \pm 0.88 \mathrm{~d})$ and $80 \%$ maturity (175.33 $\pm 0.33 \mathrm{~d})$.

The association among the agronomical traits was estimated by correlation analysis (table 5). Plant height exhibited highly significant positive correlation with grain yield $(\mathrm{r}=0.577)$ while significant positive correlation with straw yield $(\mathrm{r}=0.441)$ was detected. Highly significant positive correlation $(\mathrm{r}=0.568)$ was found between grain yield and straw yield. Days to 50\% heading exhibited highly significant positive correlation with straw yield $(\mathrm{r}=$ 0.597). Highly significant positive correlation between plant height and grain yield was also reported by Ulaganathan and Nirmalakumari [19], Assefa and Fetene [20] and Duke [9]. Similarly, Bastola et al. [2] found highly significant positive inter-correlation between plant heights, grain yield per plant, days to 50\% flowering and straw yield per plant. The present findings are in concordance with Ulganathan and NirmalaKumari [19], Bastola et al. [2], Duke [9] and Assefa and Fetene [20].

Table 6 presents the principal component and \% of contribution of each component to the total in the finger millet genotypes. The first accounted for $43.07 \%$ of the total variation in the population. Plant height, grain yield, straw yield and days to $50 \%$ heading contributed more to the first component. Second principal component 
accounted for $24.76 \%$ of total variation. Number of fingers per head and grain yield contributed heavily to the second component in positive direction while 1000 grain weight and days to $80 \%$ maturity contributed more to the second component in negative direction. The third principal component accounted for $15.07 \%$ of the total variation. 1000 grain weight and grain yield contributed more to the third component in positive direction while days to $80 \%$ maturity contributed more to the third component in negative direction. The first three principal components with Eigen value $\geq 1$ accounted for $82.89 \%$ of the total variation. Similar findings with regard to grain yield per plant, plant height and days to flowering were reported by Salini et al. [21] and Ulaganathan and Nirmalakumari [19] in prosomillet and finger millet, respectively. Previous studies support the findings [22-25]. The present finding indicated that indirect selection based on plant height, days to $50 \%$ heading and straw yield would be instrumental in identifying superior genotypes for finger millet crop improvement programme.
Despite the promise of the finger millet in regard to climate change adaptation, medicinal and nutritional benefits, cultivation trend of finger millet is decreasing in Nepal [26, 27] because of various socioeconomic constraints such as labour-intensive farming practice and post-harvest processing difficulties, identification of location specific varieties and unsupportive agricultural policies. In order to address these challenges, GEF/UNEP funded project on Local Crops [28] prioritized research on i) Participatory variety selection and grass root breeding to improve productivity and tolerance to stress [29]; ii) Diversity sourcing of seeds to match farmers' needs through rapid detection, on-farm evaluation and dissemination of choice varieties, iii) Technology diversification for processing and value chain enhancement of local crops, and iv) Community seed banks establishment for strengthening local seed security and agro-biodiversity conservation [30].

Table 1: List of landraces of finger millet al. ong with their collection site included in the diversity block trial in Lamjung in 2015

\begin{tabular}{|c|c|c|c|c|c|}
\hline Entry & Local name & Collection site & Entry & Local Name & Collection Site \\
\hline 1 & Setokodo & Bhojpur & 24 & Chayalte/Seto & Dolakha \\
\hline 2 & Dhankodo & Bhojpur & 25 & Seto Mudke & Dolakha \\
\hline 3 & Nangrekodo & Bhojpur & 26 & Syakkhad & Dolakha \\
\hline 4 & Nangkatuwakodo & Dhankuta & 27 & Bikase Lamo & Dolakha \\
\hline 5 & Kattikekodo & Sankhuwasabha & 28 & Bikase & Dolakha \\
\hline 6 & Chhatrekodo & Tehrathum & 29 & Paheli & Dolakha \\
\hline 7 & Andhikholekodo & Lamjung & 30 & Nangre & Dolakha \\
\hline 8 & Baidikodo & Tanahun & 31 & Seto & Dolakha \\
\hline 9 & Kalomaurelo & Kaski & 32 & Mathillo Paheli & Dolakha \\
\hline 10 & Jhupekodo & Baglung & 33 & Laribari & Dolakha \\
\hline 11 & Jhyapekodo & Kaski & 34 & Dalo Dalle & Dolakha \\
\hline 12 & Lurkekodo & Parbat & 35 & Chalyte & Dolakha \\
\hline 13 & Kattikekodo & Syangja & 36 & Botange & Dolakha \\
\hline 14 & Jhaprekodo & Gulmi & 37 & Seto & Lamjung \\
\hline 15 & Dallekodo & Ramechhap & 38 & Sangle & Lamjung \\
\hline 16 & Nuwakotekodo & Solukhumbu & 39 & Larfare & Lamjung \\
\hline 17 & Local kodo & Gorkha & 40 & Khro & Lamjung \\
\hline 18 & Kodo & Baitadi & 41 & Lafre & Lamjung \\
\hline 19 & Kalokodo & Darchula & 42 & Kekro & Lamjung \\
\hline 20 & Kabrekodo & Mustang & 43 & Dalle & Lamjung \\
\hline 21 & Kyarkodo & Sindhupalchok & 44 & Nangre & Lamjung \\
\hline 22 & Local kodo & Baitadi & 45 & Lamsare & Lamjung \\
\hline 23 & Dalle & Dolakha & 46 & Chhangre & Lamjung \\
\hline
\end{tabular}

Table 2: List of finger millet genotypes included in the yield trial during 2016 along with their distinguishing traits and sources

\begin{tabular}{|c|c|c|c|}
\hline $\begin{array}{l}\text { S. } \\
\text { No. }\end{array}$ & Genotypes & Distinguishing traits & Source \\
\hline 1 & NGRCo1431 (Chhatre) & Spike looks like umbrella & Lamjung \\
\hline 2 & Chhangre kodo & Light red, medium sized grain, erect finger/spike & Lamjung \\
\hline 3 & Nangre kodo & Spike looks like claw & Lamjung \\
\hline 4 & Dalle kodo & Compact head and closed fingers & Lamjung \\
\hline 5 & Lamsare kodo & Tiny black grains & Lamjung \\
\hline 6 & Syakhkhad kodo & Green compact ear with slightly incurved finger & Dolakha \\
\hline 7 & NGRCo5050 (Kabre-2) & Green compact ear with green nodal pigmentation & NAGRC* \\
\hline 8 & NGRCo5049 (Sailung-1) & Compact ear with incurved finger with purple node & NAGRC $^{*}$ \\
\hline
\end{tabular}

* National Agricultural Genetic Resources Centre (1350 masl), Khumaltar, Nepal 
Table 3: Number of genotypes in each cluster along with mean value \pm SD and range of agro-morphological traits

\begin{tabular}{|c|c|c|c|c|c|c|c|c|}
\hline Cluster & Member & $\begin{array}{l}\text { Days to } \\
\text { heading }\end{array}$ & $\begin{array}{l}\text { Days to } \\
\text { maturity }\end{array}$ & $\begin{array}{l}\text { Plant } \\
\text { height } \\
\text { (cm) }\end{array}$ & $\begin{array}{l}\text { Ear } \\
\text { exertion } \\
\text { (cm) }\end{array}$ & $\begin{array}{l}\text { Flag leaf } \\
\text { length } \\
(\mathrm{cm})\end{array}$ & $\begin{array}{l}\text { Finger } \\
\text { width }(\mathrm{mm})\end{array}$ & $\begin{array}{l}\text { Grain } \\
\text { yield } \\
\left(\mathbf{t} \mathbf{h a}^{-1}\right)\end{array}$ \\
\hline $\mathrm{I}$ & 9 & $\begin{array}{l}107 \cdot 55 \pm 6.21 \\
(98-117)\end{array}$ & $\begin{array}{l}156.77 \pm 7.05 \\
(150-166)\end{array}$ & $\begin{array}{l}113.67 \pm 17.65 \\
(102-125)\end{array}$ & $\begin{array}{l}14.67 \pm 1.58 \\
(12-17)\end{array}$ & $\begin{array}{l}29 \pm 2.50 \\
(25-32)\end{array}$ & $\begin{array}{l}8.44 \pm 0.53 \\
(8-9)\end{array}$ & $\begin{array}{l}0.74 \pm 0.37 \\
(0.37- \\
1.56)\end{array}$ \\
\hline II & 30 & $\begin{array}{l}126.33 \pm 6.29 \\
(114-136)\end{array}$ & $\begin{array}{l}174.17 \pm 9.53 \\
(152-194)\end{array}$ & $\begin{array}{l}123.07 \pm 13.29 \\
(94-143)\end{array}$ & $\begin{array}{l}15.67 \pm 2.77 \\
(11-23)\end{array}$ & $\begin{array}{l}31.20 \pm 3 \cdot 74 \\
(23-39)\end{array}$ & $\begin{array}{l}9.13 \pm 1.07 \\
(7-12)\end{array}$ & $\begin{array}{l}1.90 \pm 0.70 \\
\left(0.71^{-}\right. \\
3.17)\end{array}$ \\
\hline III & 3 & $\begin{array}{l}134.67 \pm 2.31 \\
(132-136)\end{array}$ & $\begin{array}{l}180 \pm 13.45 \\
(165-191)\end{array}$ & $\begin{array}{l}103 \pm 6.08 \\
(99-110)\end{array}$ & $\begin{array}{l}16 \pm 1.00 \\
(15-17)\end{array}$ & $\begin{array}{l}32.67 \pm 3.51 \\
(29-36)\end{array}$ & $\begin{array}{l}7.67 \pm 0.57 \\
(7-8)\end{array}$ & $\begin{array}{l}1.17 \pm 0.36 \\
(0.82- \\
1.55)\end{array}$ \\
\hline IV & 3 & $\begin{array}{l}138.33 \pm 8.02 \\
(130-146)\end{array}$ & $\begin{array}{l}193.67 \pm 12.70 \\
(179-201)\end{array}$ & $\begin{array}{l}112.33 \pm 9.29 \\
(102-120)\end{array}$ & $\begin{array}{l}10.67 \pm 3.79 \\
(8-15)\end{array}$ & $\begin{array}{l}31.33 \pm 3.05 \\
(28-34)\end{array}$ & $9 \pm 0.00$ & $\begin{array}{l}1.83 \pm 0.89 \\
\left(0.80^{-}\right. \\
2.35)\end{array}$ \\
\hline $\mathrm{V}$ & 1 & 130 & 184 & 121 & 14 & 37 & 12 & 3.81 \\
\hline
\end{tabular}

fig. in the parentheses indicate the range of agro-morphological traits within each cluster

Table 4: Mean values \pm Standard Error (S.E.) of agro-morphological traits of eight selected finger millet genotypes tested at Ghanpokhara VDC-1, Lamjung in 2016

\begin{tabular}{|c|c|c|c|c|c|c|c|}
\hline Genotypes & $\begin{array}{l}\text { Plant height } \\
\text { (cm) }\end{array}$ & $\begin{array}{l}\text { No. of } \\
\text { fingers } \\
\text { head-1 }^{-1}\end{array}$ & $\begin{array}{l}\text { Grain } \\
\text { yield } \\
\left(t_{\mathbf{h a}^{-1}}\right)\end{array}$ & $\begin{array}{l}\text { 100o } \\
\text { grain } \\
\text { weight (g) }\end{array}$ & $\begin{array}{l}\text { Straw yield } \\
\left(\mathrm{t} \mathrm{ha}^{-1}\right)\end{array}$ & $\begin{array}{l}\text { Days to 50\% } \\
\text { heading }\end{array}$ & $\begin{array}{l}\text { Days to } \\
80 \% \\
\text { maturity }\end{array}$ \\
\hline $\begin{array}{l}\text { Chhangre } \\
\text { Kodo }\end{array}$ & $108.67 \pm 3.28 \mathrm{a}$ & $\begin{array}{l}10.00 \pm 1.00 a \\
b\end{array}$ & $1.44 \pm 0.10 b$ & $2.77 \pm 0.03 \mathrm{~d}$ & $5.50 \pm 0.10 c d$ & $140.33 \pm 0.67 \mathrm{~cd}$ & $193.33 \pm 0.33 b$ \\
\hline Dalle Kodo & $86.67 \pm 3.67 \mathrm{c}$ & $\begin{array}{l}9.33 \pm 0.88 \mathrm{ab} \\
\mathrm{c}\end{array}$ & $1.51 \pm 0.05 \mathrm{~b}$ & $\begin{array}{l}3.23 \pm 0.03 a \\
b\end{array}$ & $5.06 \pm 0.06 \mathrm{~d}$ & $\begin{array}{l}138.00 \pm 0.58 d \\
e\end{array}$ & $189.67 \pm 0.67 \mathrm{c}$ \\
\hline $\begin{array}{l}\text { Lamsare } \\
\text { Kodo }\end{array}$ & $108.33 \pm 2.40 \mathrm{a}$ & $7.00 \pm 0.00 d e$ & $1.71 \pm 0.18 \mathrm{ab}$ & $\begin{array}{l}3.23 \pm 0.06 \mathrm{a} \\
\mathrm{b}\end{array}$ & $6.67 \pm 0.25 \mathrm{ab}$ & $141.67 \pm 0.33 b c$ & $194.67 \pm 0.88 b$ \\
\hline $\begin{array}{l}\text { Nangre } \\
\text { Kodo }\end{array}$ & $99.67 \pm 2.85 \mathrm{~b}$ & $\begin{array}{l}8.33 \pm 0.67 b c \\
d\end{array}$ & $\begin{array}{l}1.55 \pm 0.05 \mathrm{a} \\
\mathrm{b}\end{array}$ & $3.17 \pm 0.07 b c$ & $\begin{array}{l}5.61 \pm 0.06 b c \\
\text { d }\end{array}$ & $136.67 \pm 0.88 \mathrm{e}$ & $175.33 \pm 0.33 d$ \\
\hline $\begin{array}{l}\text { NGRCo1431 } \\
\text { (Chhatre) }\end{array}$ & $109.33 \pm 1.45^{a}$ & $10.67 \pm 0.33 a$ & $1.80 \pm 0.06 \mathrm{a}$ & $2.47 \pm 0.07 \mathrm{e}$ & $6.39 \pm 0.06 b c$ & $\begin{array}{l}142.33 \pm 1.33 a b \\
c\end{array}$ & $188.33 \pm 0.33 c$ \\
\hline $\begin{array}{l}\text { NGRCo5O4 } \\
9 \text { (Sailung- } \\
\text { 1) }\end{array}$ & $\begin{array}{l}101.67 \pm 3.76 a \\
b\end{array}$ & $7.67 \pm 0.33 \mathrm{cde}$ & $1.10 \pm 0.09 c$ & $3.33 \pm 0.07 a$ & $5.61 \pm 0.11 \mathrm{bcd}$ & $143.67 \pm 1.67 \mathrm{ab}$ & $\begin{array}{l}198.00 \pm 0.00 \\
\mathrm{a}\end{array}$ \\
\hline $\begin{array}{l}\text { NGRCo5O5 } \\
\text { o (Kabre-2) }\end{array}$ & $84.67 \pm 3.06 c$ & $6.00 \pm 0.00 \mathrm{e}$ & $0.89 \pm 0.04 \mathrm{c}$ & $2.60 \pm 0.06 \mathrm{e}$ & $5.17 \pm 0.10 d$ & $138.33 \pm 1.20 d e$ & $188.67 \pm 0.33 c$ \\
\hline $\begin{array}{l}\text { Syakhkhad } \\
\text { Kodo }\end{array}$ & $\begin{array}{l}104.00 \pm 1.73 a \\
b\end{array}$ & $7.33 \pm 0.33$ de & $1.83 \pm 0.10 a$ & $3.07 \pm 0.03 \mathrm{c}$ & $7.61 \pm 1.03 a$ & $145.00 \pm 1.00 a$ & $\begin{array}{l}194.00 \pm 0.58 \\
\mathrm{~b}\end{array}$ \\
\hline$p$-value & 0.0001 & 0.0007 & $<0.00001$ & $<0.00001$ & 0.0032 & 0.0001 & $<0.00001$ \\
\hline SE. $\mathrm{m} \pm$ & 3.93 & 0.82 & 79.66 & 0.08 & 0.31 & 1.30 & 0.65 \\
\hline $\begin{array}{l}\operatorname{LSD}(p \\
\leq 0.05)\end{array}$ & 8.44 & 1.75 & 170.85 & 0.16 & 0.67 & 2.78 & 1.40 \\
\hline CV (\%) & 4.80 & 12.06 & 11.00 & 3.11 & 10.75 & 1.13 & 0.42 \\
\hline
\end{tabular}

Mean values in columns with different letters are significantly different ( $p \leq 0.05)$ according to Fisher's LSD test

Table 5: Correlation matrix between different agro-morphological traits of finger millet

\begin{tabular}{|c|c|c|c|c|c|c|}
\hline $\begin{array}{l}\text { Agro-morphological } \\
\text { traits }\end{array}$ & $\begin{array}{l}\text { Plant } \\
\text { height }\end{array}$ & $\begin{array}{l}\text { No. of fingers } \\
\text { head }^{-1}\end{array}$ & $\begin{array}{l}\text { Grain } \\
\text { yield }\end{array}$ & $\begin{array}{l}\text { 1000 grain } \\
\text { weight }\end{array}$ & $\begin{array}{l}\text { Straw } \\
\text { yield }\end{array}$ & $\begin{array}{l}\text { Days to } 50 \% \\
\text { heading }\end{array}$ \\
\hline No. of fingers head ${ }^{-1}$ & .392 & & & & & \\
\hline Grain yield & $.577^{* *}$ & .359 & & & & \\
\hline 1000 grain weight & -.077 & -.288 & .065 & & & \\
\hline Straw yield & $.441^{*}$ & -.105 & $.568^{* *}$ & .065 & & \\
\hline Days to $50 \%$ heading & .383 & -.105 & .262 & .068 & $.597^{* *}$ & \\
\hline Days to $80 \%$ maturity & .208 & -.124 & -.080 & .131 & .215 & $.635^{* *}$ \\
\hline
\end{tabular}

** Correlation coefficient is significant at $p \leq 0.01$ (2-tailed), * Correlation coefficient is significant at $p \leq 0.05$ (2-tailed) 
Table 6: Eigen values, factor scores and contribution of first four principal component axes to the variation in eight selected finger millet genotypes

\begin{tabular}{|c|c|c|c|c|}
\hline Agro-morphological traits & PC1 & PC2 & PC3 & PC4 \\
\hline Eigen values & 3.0149 & 1.7329 & 1.0547 & 0.7576 \\
\hline Variance (\%) & 43.07 & 24.76 & 15.07 & 10.82 \\
\hline Cumulative variance (\%) & 43.07 & 67.83 & 82.89 & $93 \cdot 72$ \\
\hline Plant height & -0.4796 & 0.2087 & -0.0517 & -0.1283 \\
\hline No. of fingers head ${ }^{-1}$ & -0.121 & 0.6052 & -0.2493 & -0.5478 \\
\hline Grain yield & -0.4193 & 0.3762 & 0.3751 & 0.0383 \\
\hline 1000 grain weight & -0.028 & -0.3399 & 0.7128 & -0.5832 \\
\hline Straw yield & -0.5067 & -0.0724 & 0.22 & 0.4558 \\
\hline Days to $50 \%$ heading & -0.4935 & -0.3003 & -0.229 & -0.0005 \\
\hline Days to $80 \%$ maturity & -0.2802 & -0.4876 & -0.4308 & -0.3662 \\
\hline
\end{tabular}

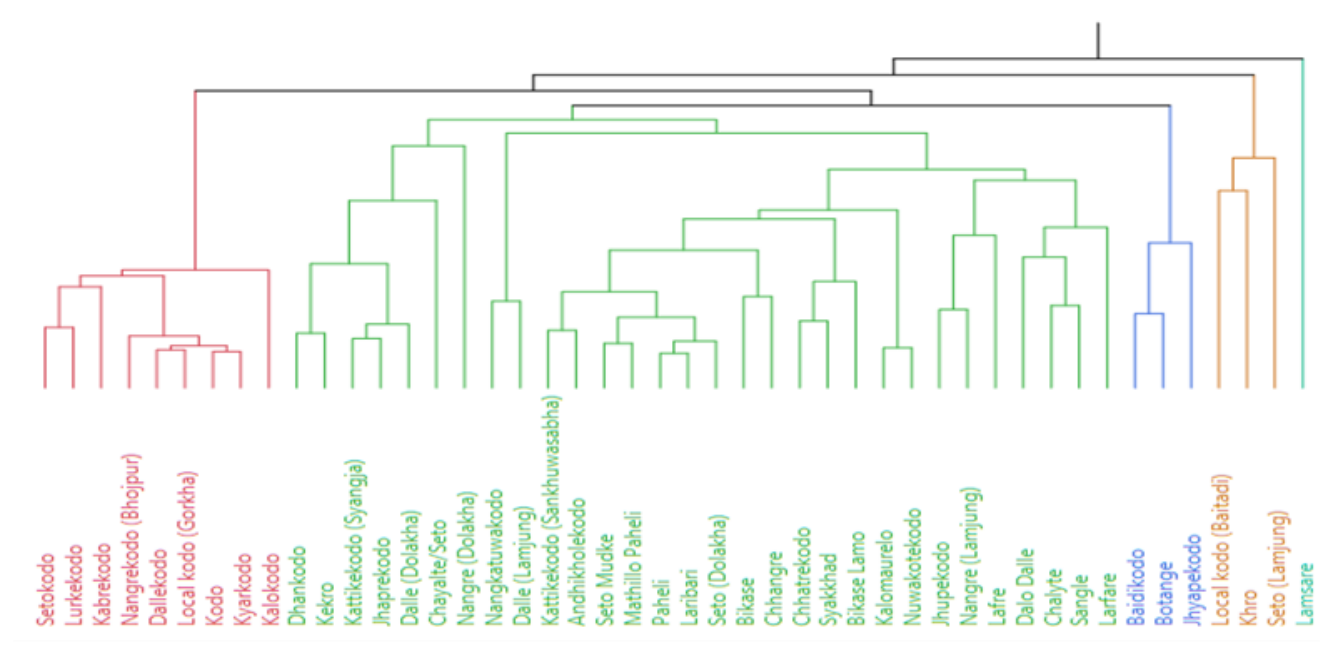

Fig. 1: UPGMA clustering of 46 finger millet genotypes included in diversity block based on average linkage and Euclidean distance

The present investigation, which is part of sourcing local crop diversity that matches farmer's needs, suggests existence of high level of phenotypic diversity among the finger millet genotypes which would be useful for choosing the genitors for crop improvement programme [31]. The evaluation studies facilitated the identification of robust finger millet varieties viz., Syakhkhad kodo, Lamsare kodo and Nangre kodo, diversifying the varietal choices for the farmers in state of very few promising cultivars available in national agricultural system. The findings bolsters the large scale testing of IRD kits for popularizing the variety [31] and registration in national agricultural system. In addition to this, community seed banks (CSBs) and district agriculture development offices (DADOs) can play a pivotal role in popularizing these robust varieties at community level via establishment of demonstration plots and distribution of IRD kits and, ensuring the accessibility of quality seeds by incorporating them in their routine conservation and seed multiplication activity. The wider dissemination and adoption of these robust finger millet varieties will assure augmented production and area coverage of finger millet in the mid-hills warranting food security in the region.

\section{ACKNOWLEDGEMENTS}

This paper is the output of the GEF (Global Environment Facility)/UNEP (United Nations Environment Programme) supported project entitled "Integrating Traditional Crop Genetic Diversity into Technology: Using a Biodiversity Portfolio Approach to Buffer against
Unpredictable Environmental Change in the Nepal Himalayas" implemented in Nepal. The project is coordinated by the Bioversity International in collaboration with Nepal Agricultural Research Council (NARC), Department of Agriculture (DoA) and Local Initiatives for Biodiversity Research and Development (LIBIRD). Authors would like to acknowledge Dr. BK Joshi (NAGRC), Dr. MN Paudel (NAGRC), Mr. Kamal Khadka (LI-BIRD) and Dr. D Gauchan (Bioversity International) for technical support and encouragement.

\section{AUTHOR'S CONTRIBUTIONS}

Authors contributed equally to the overall study and manuscript preparation and approved the final version of the manuscript for publication.

\section{REFERENCES}

1. Sherchan K. Importance, genetic resources and varietal improvement of finger millet in Nepal. In: Small Millets in Global Agriculture. Eds. Seetharam A, Riley KW, Harinarayana G. Oxford and IBH Pub. Co. Pvt. Ltd. New Delhi. Pp 85-92. 1989.

2. Bastola BR, Pandey MP, Ojha BR, Ghimire SK and Baral K. Phenotypic diversity of Nepalese finger millet (Eleusine coracana (L.) Gaertn.) accessions at IAAS, Rampur, Nepal. Int. J. Appl. Sci. Biotechnol., 2015;3: 285-290.

3. Holt J. Investigation into the biology, epidemiology and management of finger millet blast in low-input farming systems in East Africa. 2000. Retrieved on June 8, 2016 
from http://www. wisard. org/wisard/shared/asp/ projectsummary. asp/Kennumer

4. ICRISAT. Finger millet. 2004. Retrieved on 15 July, 2004 from http://www. icrisat. org/web/ASP/mainsection. asp/

5. Bhatt D, Negi M, Sharma P, Saxena SC, Dobriyal AK, Arora S. Responses to drought induced oxidative stress in five finger millet varieties differing in their geographical distribution. Physiol. Mol. Biol. Plants. 2011;17:347-353.

6. LMA. Finger millet: Eleusine coracana. Sri-Lankan Ministry of Agriculture. Department of Agriculture. 2004. Retrieved on 15 July, 2004 from http://www. gov. lk/Agriculture/Agridept/Techinformations/Cgrains/Fmi llet. Html

7. Goron TL, Raizada MN. Genetic diversity and genomic resources available for the small millet crops to accelerate a new green revolution. Rev. Front. Plant Sci. 2015;6:1-17.

8. Devi PB, Vijayabharathi R, Sathyabama S, Malleshi NG, Priyadarisini VB. Health benefits of finger millet (Eleusine coracana L.) polyphenols and dietary fibre: a review. J. Food Sci. Technol. 2014;51:1021-1040.

9. Duke JA. Handbook of Energy Crops. Purdue University, Center for new crops and plant products, Unpublished. 1983. From http://www. hort. purdue. edu/newcrop/Duke_energy/dukeindex. html

10. Vietmeyer ND. Lost crops of Africa (Vol: I) Grains. National Academy of Sciences, National Academy Press, Washington, D. C. USA. Pp 39-57. 1996.

11. National Research Council. Lost crops of Africa. Vol. I: Grains. National Academy Press, Washington, DC, USA. Pp 383. 1996

12. Hodgkin T, Ramanatha Rao V, Cibrian-Jaramillo A, Gaiji S. The use of ex situ conserved plant genetic resources. Plant Genet. Resour. 2003;1: 19-29.

13. Tiwari R, Sthapit BR, Shrestha P, Baral K, Subedi A, Bajracharya $J$ and Yadav RB. Diversity Block: Assessing and Demonstrating Local Diversity. In: Sthapit BR, Shrestha P, Upadhyay MP, editors. Onfarm Management of Agricultural Biodiversity in Nepal: Good Practices. Nepal: NARC/lIBIRD/Bioversity International; 2006. p. 29-32.

14. IBPGR. Descriptors for finger millet. International Board for Plant Genetic Resources, Rome, Italy. 1985

15. Naik BJ, Shankare Gounda BT, Seetharam A. Pattern of variability in relation to domestication of finger millet in Africa and India. In: Advances in Small Millets (Eds. Riley KE, Gupta SC, Seetharam A, Mushonga JN). International Science, New York. Pp 347-363. 1994

16. Prasado Rao KE, De Wet JMJ, Gopal Reddy V, Mengesha MH. Diversity in the small millets collection at ICRISAT. In: Advances in small millets (Eds Riley KE, Gupta SC, Seetharam A, Mushonga JN). International Science Publisher, New York, USA. Pp 331-345. 1994.

17. John K. Variability and correlation studies in quantitative traits of finger millet (Eleusine coracana Gaertn). Agric. Sci. Digest. 2006;26: 166-189.

18. Sonnad S, Shanthakumar G, Salimath PM. Genetic variability and character association studies in White
Ragi (Eleusine coracana Gaertn.). Karnataka J. Agric. Sci. 2008;21: 572-575.

19. Ulaganathan V, Nirmalakumari A. Finger millet germplasm characterization and evaluation using principal component analysis. J. Breeding and Genetics. 2015;47: 79-88.

20. Assefa A, Fetene M. Agro-morphological, physiological and yield related performances of finger millet [Eleusine coracana (1.) Gaertn.] accessions evaluated for drought resistance under field condition. Asian J. Agr. Rural Dev. 2013;3:709-720.

21. Salini KA, Nirmalakumari A, Muthiah R, Senthil N. 2010. Evaluation of proso millet (Panicum miliaceum L.) germplasm collections. Elect. J. Plant Breed. 2010;1: 489-499.

22. Khavari Khorasani S, Mostafavi KH, Zandipour E, Heidarian A. Multivariate analysis of agronomic traits of new corn hybrids (Zea mays L.). Int. J. Agric. Sci. 2011;1: 314-322.

23. Azad MK, Biswas BK, Alam NS, Alam KS. 2012. Genetic diversity in maize (Zea mays L.) inbred lines. The Agriculturists, 2012;10: 64-70.

24. Negash W, Asfaw Z, Yibra H. 2005. Variation and association analysis on morphological characters of Linseed (Linum usitatissimum L.) in Ethiopia. Ethiop. J. Sci.,2005;28:129-140.

25. Assefa K, Arnulf M, Tefera H. Multivariate analysis of diversity of tef [Eragrostis tef (Zucc.) Trotter] germplasm from western and south western Ethiopia. Hereditas, 2003;138:228-236.

26. Gurung R., Sthapit SR, Gauchan D, Joshi BK, Sthapit BR. Baseline Survey Report: II. Ghanpokhara, Lamjung. Integrating Traditional Crop Genetic Diversity into Technology: Using a Biodiversity Portfolio Approach to Buffer against Unpredictable Environmental Change in the Nepal Himalayas. LIBIRD, NARC and Bioversity International, Pokhara, Nepal. 2016

27. Pudasaini N, Sthapit SR, Gauchan D, Bhandari B, Joshi BK, Sthapit BR.2016. Baseline Survey Report: I. Jungu, Dolakha. Integrating Traditional Crop Genetic Diversity into Technology: Using a Biodiversity Portfolio Approach to Buffer against Unpredictable Environmental Change in the Nepal Himalayas. Pokhara, Nepal: LI-BIRD, NARC, DOA and Bioversity International. 2016

28. www. himalayancrops. org

29. Sthapit BR, Ramanatha Rao V. Consolidating community's role in local crop development by promoting farmer innovation to maximise the use of local crop diversity for the well-being of people. Acta Hort. 2009;806:669-676.

30. Vernooy R, Sthapit BR, Galluzzi G, Shrestha P. The Multiple functions and services of community seed banks. Resources. 2014;3:636-656.

31. Witcombe JR, Khadka K, Puri RR, Khanal NP, Sapkota A, Joshi KD. Adoption of rice varieties. 2. Accelerating uptake. Expl Agric. 2016. doi: 10.1017/So014479716000624 